\title{
Cloniophora plumosa (Cloniophoraceae, Ulvales): A new addition to the Algal Flora of India
}

\author{
Vianny Animica F*, Aron Santhosh Kumar Y and Palanisamy M \\ Botanical Survey of India, Southern Regional Center \\ Tamil Nadu Agriculture University Campus, Lawley Road, Coimbatore - 641003 \\ *Corresponding author: viannyeva@gmail.com
}

\section{क्लोनिफोरा प्लूमोसा (क्लोनियोफोरेसी, उलवेलिस) भारत के शैवालीय फ़्लोरा में एक नवीन संकलन}

वियानी अनिमिका एफ, आरोन संतोष कुमार वाई एवं पलनीसामी एम

\section{सारांश}

क्लोनिफेरा टिफेनी क्लोरोफाइसी वर्ग के अंतर्गत उलवेलिस का एक विशिष्ट वंश है। वंश का सवितरण एवं विविधता अलवणीय जल के साथ-साथ विश्व के कुछ भागों के समुद्र जलीय आवासों से आलेखित किए गए हैं। इसकी आकृतिकी स्टिजियोक्लोनियम एवं ड्रेपरनालडिया से समानता प्रदर्शित करती है, जब दोनों वंशों के लक्षणों का अध्ययन किया जाता है। साथ ही अपने शाखीय प्रतिरूप, अग्रस्थ कोशिका की आकृति, एवं अग्रस्थ कोशिका में बालों की अनुपस्थिति के कारण यह अन्य वंशों से भिन्न होती है। विश्व भर से यह 6 जातियों को शामिल करती है, उनकें से सी. स्पिकाटा एवं सी. मेक्रोक्लेडिया को भारत से अभिलेखित किया गया है। वर्तमान अध्ययन तमिलनाडू में कोयंबटूर के कुमारासामी झील से क्लोनिफोरेसी के क्लोनिफोरा प्लूमोसा (कुएटज) बर. की उपस्थिति को बताता है। एक छायाचित्र पट्ट के साथ विस्तृत वर्गिकीय विवरण यहाँ प्रदान किया गया है। अपेक्षाकृत अच्छी समझा के लिए भारतीय टैक्सा के साथ एक तुलनात्मक कुंजी दी गई है।

\begin{abstract}
Cloniophora Tiffany is a distinct genus of Ulvales under the class Chlorophyceae. The distribution and diversity of the genus was recorded in the freshwater as well as in marine water habitats from the fewer parts of the world. It has morphological resemblance with the Stigeoclonium and Draparnaldia by obtaining characters of both genera. Also, it is distinguished from other genera through the branching pattern, the shape of apical cell, and the absence of apical hair. It includes 6 species in worldwide, among them, C. spicata and C. macrocladia are reported from India. The present study revealed the presence of Cloniophora plumosa (Kuetz.) Bourr. of Cloniophoraceae from the Kumarasamy Lake, Coimbatore, Tamil Nadu. This species is reported for the first time from the fresh water bodies of India. The details taxonomical description, along with a photo plate is provided here. A comparative key with Indian taxa is also been provided for better understanding.
\end{abstract}

Keywords: Coimbatore, Fresh water algae, Kumarasamy Lake, New distributional addition

\section{INTRODUCTION}

The genus Cloniophora Tiffany (1937) is a less common species where its distribution is known only from a few parts of the world so far. It is a feathery tufted algae generally found attached to substrata such as stones, ropes, and rocks. It is also found on other floating substances in the water bodies. Cloniophora has shown its presence in both freshwater and brackish water. This genus shows a very close morphological similarity with the genera Stigeoclonium and Draparnaldia by acquiring characters of both genus. The genus Cloniophora is been differentiated by its branching pattern, the shape of apical cell, and the 
absence of apical hair (Islam, 1961). Recent molecular studies on this genus have revealed that, Cloniophora forms the novel linage with Ulvales under the new family Cloniophoraceae (Carlile \&.al. 2011), which was formerly placed in Chaetophorales based on their morphological character. The genera comprises of 6 species worldwide, of which two species are reported in India viz. Cloniophora spicata ( Schmidle) A. K. Islam \& Cloniophora macrocladia (Nordstedt) Bourr. (Gupta, 2012, Guiry \& Guiry, 2020).

\section{MATERIALS AND METHODS}

The sample was collected from Kumarasamy Lake (11 $\left.{ }^{\circ} 00^{\prime} 04.7^{\prime \prime} \mathrm{N} \& 76^{\circ} 56^{\prime} 37.4^{\prime \prime E}\right)$, Coimbatore, Tamil Nadu along the surface of the rope submerged near the shore. The collected sample was carefully taken from the substratum and observed under Carl Zeiss AxioA10 microscope and the remaining samples were preserved using $4 \%$ formalin for further studies at BSI, SRC laboratory, Coimbatore. The observed specimen was identified with the help of relevant literatures and books Kutezing (1849), Islam (1961); Hirose \& al., (1977); Morgan \& al., (1994); Carlile \& al., (2011); Skaloud \& al., (2018).

Habit \& Habitat: Freshwater, green filamentous, feathery tufted thallus attached on ropes submerged in the water, along the shore of Kumarasamy Lake.

\section{TAXONOMIC TREATMENT}

Cloniophora plumosa (Kuetz.)Bourr. in Bourrelly \& Manguin Alg. Guadeloupe (Paris): 203. 1952; Hirose \& al., in Illustr. Japan. Fr.wat. Alg. 244:1977; P.C. Silva \& al., Cat. Benth. Mar. Alg. Ind. Ocean: 722: 1996. Gunathilaka, Wildlanka. 4: 169 - 180, 2016. Stigeoclonium plumosum Kuetz. Sp. Alg. 356: 1849.

(Plate - 1)

Plant body filamentous, feathery, tufted or caespitose, firmly attached to the substratum by minute rhizoids. Dark to light green in color, $3-5 \mathrm{~cm}$ long uniseriate, profusely or irregularly branched. The main axis capitate with or without constriction at the region of the cross wall. $20-30 \mu \mathrm{m}$ in diameter with primary branches and short secondary branches. Basal zone of plant body sparsely and apical zone splendidly branched. The apical cells obtuse to conical shape with blunt apex and it is longer than the basal cell of the filament without hair formation. During our present study we have not found any reproductive characters.
Distribution: Bangladesh, Europe, Hawaii, Japan and India (present collection from Kumarasamy Lake, Coimbatore, Tamil Nadu).

Specimen examined: INDIA-Tamil Nadu: Coimbatore District - Kumarasamy Lake, 07.09.2019, Vianny Animica CBEKSL10 (MH).

\section{DISCUSSION}

In India, Kant \& Gupta (1998) accounted the occurrence of genus Cloniophora and reported $C$. spicata and C. macrocladia for the first time from the Ladakh Lake, Kashmir, Later Vijaya Parthasarathy \& Krishnamurthy (2007) reported C. spicata from the fresh water bodies of Kanyakumari District, Tamil Nadu.

According to Islam (1961), the genus Cloniophora shares an unusual wide range of distribution. Almost all collections of the members of the genus have been documented from, running fresh water bodies in the vicinity of coast, which were highly influenced by tidal sea water. Indian Ocean records are recorded at the mouth of a river (Silva, 1996). The present investigation evidences the existence of the species Cloniophora plumosa from the Indian waters bodies for the first time.

\section{Identical features of Indian species of Cloniophora}

Cloniophora macrocladia (Nordstedt) Bourr.: Thallus repeatedly branched throughout the filament. Cells of main filament cylindrical, capitate, inflate with or without constriction, $20-46 \mu \mathrm{m}$ in diameter.

Cloniophora spicata (Schmidle) A. K. Islam:Upper part of the primary branches tufted with ramuli, lower part unbranched. Cells of main axis tumid strongly capitate slightly constricted and cells isodiametric.

Cloniophora plumosa (Kuetz.) Bourr.: Thallus repeatedly branched at upper and lower part and sparsely branched at the middle. Cells of main filament mostly cylindrical, capitate with or without constriction in partition, mostly 20-25 $\mu \mathrm{m}$ in diameter, 2-3 times as long as broad.

\section{ACKNOWLEDGEMENTS}

The authors express their sincere gratitude to the Director, BSI, Kolkata and Head of Office, BSI, SRC, Coimbatore for encouragement and providing facilities. 

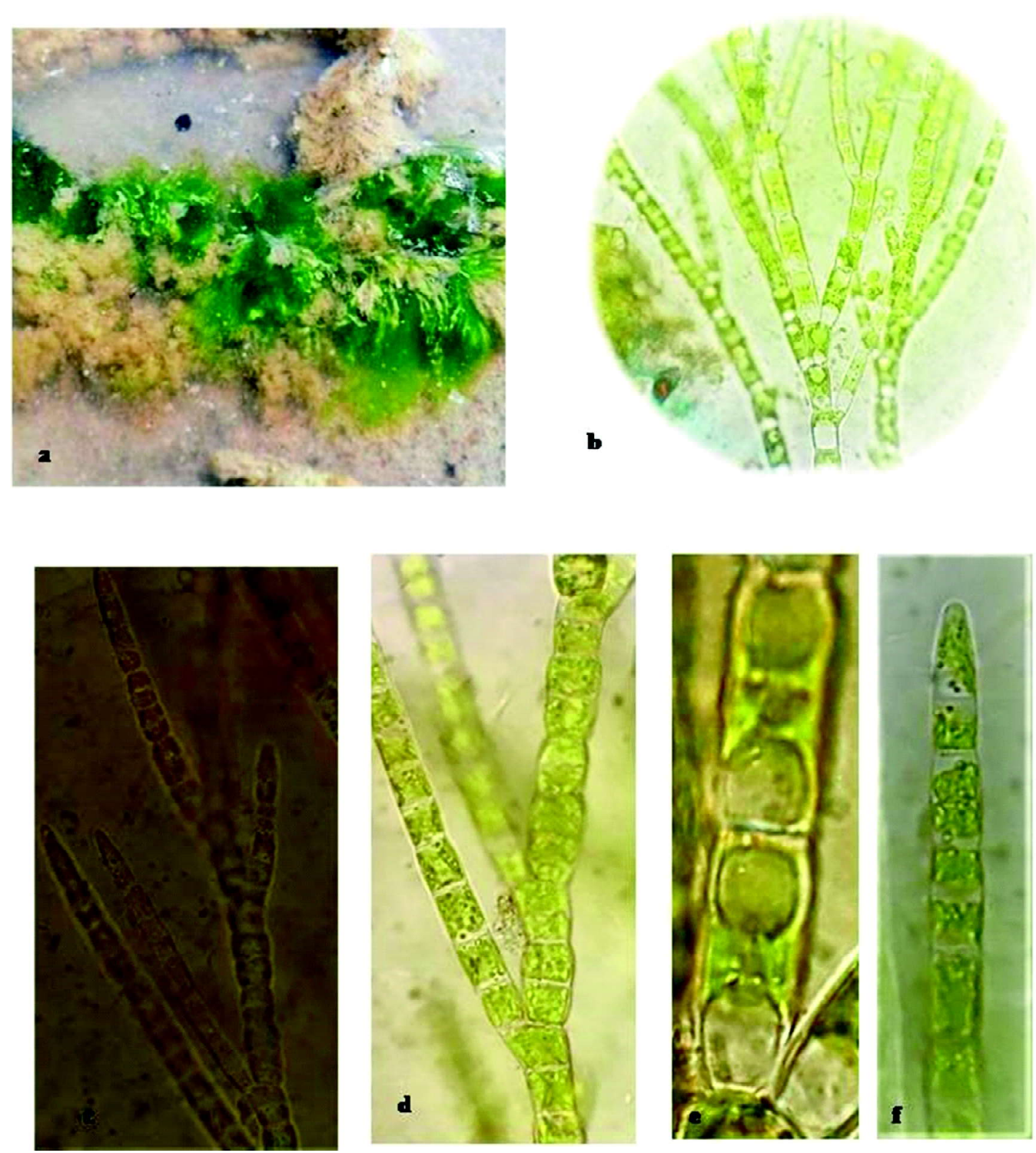

Plate - 1: a: Luxuriant Growth of Cloniophora plumosa; b: Microscopic observation of the thallus; c: Branching pattern; d \& e : Cells with and without Constriction; f: Conical shaped apical cell with blunt apex.

\section{REFERENCE}

BOURRELLY, P. 1952. Alguesd'eaudouce de la Guadeloupe etdépendances. In: Bourrelly, P. (ed.) Recueillies par la Mission P. Allorgeen. Paris.

CARLILE A.L, O' KELLY C.J. AND SHERWOOD, A. R. 2011. The green algal genus Cloniophora represents a Novel lineage in the Ulvales: A proposal for Cloniophoraceae fam. Nov. Journal of Phycology 47(6):1379-1387.
GUIRY, M.D. AND GUIRY, G.M. 2021. M.D. GUIRY IN GUIRY, M.D. AND GUIRY, G.M. 2021. AlgaeBase. World-wide electronic publication, National University of Ireland, Galway. http://www.algaebase.org; searched on 27 March 2021.

GUNATHILAKA, M.D.K.L. 2016. Unnoticed seaweeds containing Mangrove forests in Srilanka Wildlanka: 4:169- 180 .

GUPTA R.K 2012. Algae of India Volume 2. A checklist of Chlorophyceae, Xanthophyceae. Chrysophyceae and 
Euglenophyceae. Salt Lake, Kolkata: Botanical Survey of India, Ministry of Environment \& Forests.

HIROSE, H., YAMAGISHI, T., AND AKIYAMA, M. 1977. Illustrations of the Japanese Freshwater Algae. Uchida Rokakuho publishing Co., Ltd., Tokyo

HIROSE, H., AND TAKASHIMA, H. 1955. The green algal genus Cloniophora, newly found from Japan. Journal of Japanese Botany. 30 (8): 233-237.

ISLAM, A.K.M.N 1961. The genus Cloniophora Tiffany. Revue Algologique, Nouvelle Serie. 6:7-32.

KÜTZING, F.T., 1849. Species Algarum. Lipsiae.

MORGAN VIS, ROBERT G. SHEATH, JULIE A. HAMBROOK, AND KATHLEEN M. COLE. 1994. Pacific Science 48 (2): 175-187

SALAM, A.M. A AND KHAN, Y.S. A 1978. On Cloniophora plumosa (Kuetzing) Bourrelly from Bangladesh. Phykos 16:63-64.
SALAM, A.M.A., AND KHAN, Y.S.A. 1978; Algal flora of the Karan fully estuary. Phykos 17 (1-2): 99-103

SILVA, P.C., BASSON, P.W. \& MOE, R.L. 1996. Catalogue of the benthic marine algae of the Indian Ocean. University of California Publications in Botany.

SKALOUD P RINDI, F., BAEDEKER, C., AND LEIAERT, F., 2018. Freshwater flora of Central Europe: Süßwasser flora von Mitteleuropa. Vol -13 Chlorophyta: Ulvophyceae. Springer Berlin Heidelberg.

TIFFANY, L. H. 1936. Wille's collection of Puerto Rican freshwater algae. Brillonia 2 (2): 165-176

VIJAYA PARTHASARATHY, M.D. AND KRISHNAMURTHY, V.2007. On the occurrence of Cloniophora Tiffyany in Indian waters. Ind. Hydrobiol. 10(1): 153.

WHITFORD, L. A. 1960. Ecological distribution of freshwater algae, in The Ecology of Algae, The Pymatuning symposia in Ecology. University of Pittsburgh. 